\title{
Antibacterial constituents of three Cameroonian medicinal plants: Garcinia nobilis, Oricia suaveolens and Balsamocitrus camerunensis
}

Hugues Fouotsa ${ }^{1,4}$, Armelle T Mbaveng ${ }^{2,3}$, Celine D Mbazoa', Augustin E Nkengfack', Shaheen Farzana ${ }^{4}$, Choudhary M Iqbal ${ }^{4}$, Jacobus J Marion Meyer ${ }^{5}$, Namrita Lall ${ }^{5}$ and Victor Kuete $2,5^{*}$

\begin{abstract}
Background: Multidrug resistance is a worrying cause of treatment failure in bacterial infections. The search of bioactive constituents from medicinal plants against multidrug resistant (MDR) bacteria has significantly evolved in the two last decades. In the present study, twenty-two compounds (three terpenoids, eleven phenolics and eight alkaloids) isolated from three Cameroonian medicinal plants, namely Garcinia nobilis, Oricia suaveolens and Balsamocitrus camerunensis, as well as the crude extracts were tested for their antibacterial activities against Mycobacterium tuberculosis and Gram-negative bacteria amongst which were MDR active efflux pumps expressing phenotypes.
\end{abstract}

Methods: The microplate alamar blue assay (MABA) and the broth microdilution methods were used to determine the minimal inhibitory concentrations (MIC) and minimal bactericidal concentrations (MBC) of the studied samples.

Results: The results of the MIC determinations indicate that, the best crude extract was that from G. nobilis (GNB), its inhibitory effects being noted against 12 of the 14 tested bacteria. The extract of GNB also exhibited better anti-tuberculosis (MIC of $128 \mu \mathrm{g} / \mathrm{ml}$ M. tuberculosis against ATCC 27294 strain) and antibacterial (MIC of $64 \mu \mathrm{g} / \mathrm{ml}$ against Escherichia coli ATCC10536) activities compared to the extracts of O. suaveolens and B. camerunensis. Interestingly, 4-prenyl-2-(3,7-dimethyl-2,6-octadienyl)-1,3,5,8-tetrahydroxyxanthone (2), isolated from the most active extract GNB, also showed the best activity amongst compounds, inhibiting the growth of all the fourteen tested microorganisms. The lowest MIC value obtained with compound 2 was $8 \mu \mathrm{g} / \mathrm{ml}$ against M. tuberculosis ATCC 27294 and M. tuberculosis clinical MTCS2 strains. Other compounds showed selective activities with 11 of the 14 tested bacteria being sensitive to the xanthone, morusignin I (5) and the alkaloid, kokusaginine (13).

Conclusions: The results of the present investigation provide evidence that the crude extract from G. nobilis, O. suaveolens and B. camerunensis as well as some of their compounds, and mostly compound 2 (isolated from G. nobilis,) could be considered as interesting natural antibacterial products.

Keywords: Antimycobacterial, Antibacterial, Cameroon, Compounds, Garcinia nobilis, Oricia suaveolens, Balsamocitrus camerunensis

\footnotetext{
* Correspondence: kuetevictor@yahoo.fr

${ }^{2}$ Department of Biochemistry, Faculty of Science, University of Dschang,

Dschang, Cameroon

${ }^{5}$ Department of Plant Science, Faculty of Agricultural and Biological Science,

Pretoria 0002, South Africa

Full list of author information is available at the end of the article
} 


\section{Background}

The continuous emergence of multidrug-resistant (MDR) bacteria drastically reduced the efficacy of our antibiotic armory and, consequently, increases the frequency of therapeutic failure. Drug resistance is a consequence of the worldwide use of antibiotics, and the acute challenge for health care is to find measures to efficiently combat resistant organisms [1]. Several natural compounds have successfully been tested for their abilities to prevent the growth of MDR bacteria [2]. In our continuous search of antibacterial drugs from natural source, we targeted three Cameroonian medicinal plants, Garcinia nobilis Engl. (Clusiaceae), Oricia suaveolens Engl. [Commonly known in West Africa as Abe iolo or Kru-bete parihi (Ivory Coast) or Mende jagbole (Sierra Leone)] and Balsamocitrus camerunensis Letouzey, R. (Rutaceae). Plants of the genus Garcinia, widely distributed in the tropical Africa, Asia, New Caledonia, and Polynesia, have yielded many biologically active and structurally intriguing natural products [3]. Garcinia species are known to contain a wide variety of oxygenated and prenylated xanthones, as well as polyisoprenylated benzophenones such as the guttiferones [4]. Previous studies of the chemistry of the genus Oricia, including $O$. suaveolens revealed the presence of alkaloids and triterpenes [5,6]. B. camerunensis is a new species recently found in Batouri (Cameroon) and Boukoko (Central African Republic) [7]. Plants of genus Balsamocitrus (including the decoction of the bark of B. camerunensis) are used in traditional African medicine to treat malaria, hypertension, infertility, and influenza $[8,9]$. Previous phytochemical investigations of this genus revealed the presence of coumarins, quinoline alkaloids, free aliphatic acids and steroids, some of these compounds exhibiting potent antibacterial, fungicidal, and algicidal properties [8]. The aqueous decoctions of the bark of G. nobilis as well as that of the roots of $O$. suaveolens are used in Cameroon to treat gastro-intestinal infections [Personal communication]. The combination of the three plants (G. nobilis, O. suaveolens and B. camerunensis) is also used locally to treat stomachache and diarrheal infections [Personal communication]. The present study was therefore designed to evaluate the antibacterial activities of the naturally occurring compounds from G. nobilis, O. suaveolens and B. camerunensis with emphasis on MDR Gram-negative bacteria and Mycobacterium tuberculosis.

\section{Methods}

\section{General experimental procedure}

${ }^{1} \mathrm{H}$ and ${ }^{13} \mathrm{C}$ NMR spectra were recorded in chloroform on Digital NMR BRUCKER AVANCE 400 and $500 \mathrm{MHz}$. EIMS were obtained on Joel the MS route JMS.600H and HREIMS were performed on a thermo finnigan Mat 95 $\mathrm{XP}$. Thin layer chromatography (TLC) and pre-coated TLC were performed on silica gel $\mathrm{GF}_{254}$ (Merck). Column chromatography (CC) was performed on silica gel (Merck) type 100(70-230 Mesh ASTM) eluted either with gradient system (Hex-Ethyl Acetate- $\mathrm{MeOH} ; \mathrm{Hex}-\mathrm{CH}_{2} \mathrm{Cl}_{2}-\mathrm{MeOH}$ and $\mathrm{Hex}-\mathrm{CH}_{2} \mathrm{Cl}_{2}$-Acetone). All the solvents used were distilled commercial grade. The isolated compounds were crystallized from the same solvent and their purity was checked by TLC. Pre-coated plates of silica gel $\mathrm{GF}_{254}$ (Merck) were used for this purpose; the spots were detected with UV lamp at 254 and $366 \mathrm{~nm}$ and by spraying with $50 \% \mathrm{H}_{2} \mathrm{SO}_{4}$ or ceric sulfate following by heating.

\section{Plant material}

The stem bark of the G. nobilis was collected in OkolaYaounde (Center Region of Cameroon) in April, 2010 whilst $O$. suaveolens (woods and stem bark), and $B$. camerunensis (stem bark) were collected in Nkobi village (Batouri, East region of Cameroon), in August 2007. The plants were identified by Mr. Victor Nana of the Cameroon National Herbarium (Yaoundé) where voucher specimen (50779/HNC/Cam for G. nobilis, 6161/SRF/Cam for $O$. suaveolens and $3785 / \mathrm{SRFK}$ for B. camerunensis) were deposited.

\section{Extraction}

The air-dried and powdered samples from each plant were macerated in either $7.0 \mathrm{~L}$ methanol $(\mathrm{MeOH})$ for the stem bark of $\mathrm{G}$. nobilis $(2 \mathrm{~kg}$ ) or in $10 \mathrm{~L} \mathrm{MeOH} /$ dichloromethane $\left(\mathrm{CH}_{2} \mathrm{Cl}_{2}\right)$ mixture for the wood $(4 \mathrm{~kg})$ and roots $(3 \mathrm{~kg})$ of $O$. suaveolens, and the stem bark $(3.8 \mathrm{~kg})$ of $B$. camerunensis. The extraction was done at room temperature for two days. The evaporation under reduced pressure yielded the crude extracts from the stem bark of G. nobilis (GNB; $100 \mathrm{~g}$ ), wood (OSW; $173 \mathrm{~g}$ ) and roots (OSR; $145 \mathrm{~g}$ ) from O. suaveolens, and from the stem bark B. camerunensis (BCB; $128 \mathrm{~g}$ ).

\section{Isolation and identification of compounds from garcinia nobilis}

The compounds from GNB tested herein, caroxanthone (1), 3-dimethyl-2-geranyl-4-prenylbellidifolin (2), smeath xanthone A (3), 8-hydroxycudraxanthone G (4) and morusignin I (5) (Figure 1) were obtained directly from our chemical bank. We previously reported their isolation and identification from GNB [10].

\section{Isolation and identification of compounds from oricia suaveolens}

One hundred grams of OSW were submitted to vacuum liquid chromatography (VLC; 25-40 $\mu \mathrm{m}, 8 \mathrm{~cm} \times 60 \mathrm{~cm}$, $400 \mathrm{~g}$ ), eluting with $n$-hexane-Ethyl acetate (EtOAc) of increasing polarity. Fractions of $500 \mathrm{~mL}$ each were collected and subsequently pooled on the basis of their thin layer chromatography (TLC) profile into five main fractions 
[n-hexane- EtOAc 8:2 (2 L, $15 \mathrm{~g}$, fraction 1); 6:4 (2 L, $30 \mathrm{~g}$, fraction 2); 4:6 (1.5 L, $12 \mathrm{~g}$, fraction 3); 2:8 (1.5 L, $15 \mathrm{~g}$, fraction 4); 0:10 (1 L, $10.5 \mathrm{~g}$, fraction 5)]. Fraction 2 (30 g) was then subjected to silica gel 60 column chromatography $(25-40 \mu \mathrm{m}, 6 \mathrm{~cm} \times 60 \mathrm{~cm}, 100 \mathrm{~g})$, eluting with n-hexane-EtOAc mixture of increasing polarity. Subfractions (sub-fr) of $100 \mathrm{~mL}$ each were collected, then pooled into nine main sub-frs obtained as follows: $n$ hexane- EtOAc 10:0 (1 L, sub-fr A); 9:1 (1.5 L, sub-fr B); 8:2 (1.5 L, sub-fr C); 7.5:2.5 (1 L, sub-fr D); 7:3 (750 mL, sub-fr E); 6:4 (900 mL, sub-fr F); 5:5 (500 mL, sub-fr G); 3:7 (500 mL, sub-fr $\mathrm{H}$ ) and pure EtOAC (1 L, sub-fr I). Stigma-5-en-3-ol $\mathrm{C}_{29} \mathrm{H}_{50} \mathrm{O}$ (6; $88.3 \mathrm{mg} ; \mathrm{m} / z$ : 414; mp: $\left.250^{\circ} \mathrm{C}\right)$ [11] and lupeol $\mathrm{C}_{30} \mathrm{H}_{50} \mathrm{O}(7 ; 57.1 \mathrm{mg} ; \mathrm{m} / z$ : 426; mp: $215-216^{\circ} \mathrm{C}$ ) [12] were obtained from sub-frs A (4.2 g) and $B(6.0 \mathrm{~g})$ respectively by recrystallization. Sub-frs A and $B$ residues were then combined based on their similar TLC profile to obtain a new sub-fr named AB (7.5 g). The sub-fr $A B$ was purified on silica gel column $(25-40 \mu \mathrm{m}$, $4 \mathrm{~cm} \times 60 \mathrm{~cm}, 80 \mathrm{~g}$ ) using n-hexane-EtOAc with increasing polarity. Based on their TLC profiles, 15 new sub-frs of $100 \mathrm{~mL}$ each were obtained; evoxanthine $\mathrm{C}_{16} \mathrm{H}_{13} \mathrm{NO}_{4}$ (8; $30.0 \mathrm{mg} ; \mathrm{m} / z$ : 283 ; $\mathrm{mp}: 218-218^{\circ} \mathrm{C}$ ) [13] was obtained by recrystallisation from new sub-frs 3-6 ( $n$-hexaneEtOAc 8:2; 7.5:2.5; 7:3; 6.5:3.5) whilst sub-frs 9-12 ( $n$-hexane- EtOAc: $5: 5 ; 4.5: 5.5 ; 4: 6 ; 3: 7)$ yielded evoxanthidine $\mathrm{C}_{15} \mathrm{H}_{11} \mathrm{NO}_{4}\left(9 ; 18.1 \mathrm{mg} ; \mathrm{m} / z: 269 ; \mathrm{mp}: 310-312^{\circ} \mathrm{C}\right)$ by recrystallisation [14].
Sub-frs C-D (7 g) were combined on the basis of their TLC profiles, then subjected to column chromatography over silica gel $(25-40 \mu \mathrm{m} 3 \mathrm{~cm} \times 6 \mathrm{~cm}, 70 \mathrm{~g})$ and eluted with the increasing polarity $n$-hexane- EtOAc to afford ten other sub-frs. Sub-frs 2-4 (obtained with $n$-hexaneEtOAc 7:3; 6:4; 5:5, $2.6 \mathrm{~g}$ ) yielded 1-hydoxy-2,3-dimethoxy10-methylacridone or arborinine $\mathrm{C}_{16} \mathrm{H}_{15} \mathrm{NO}_{4}$ (10; $12.1 \mathrm{mg}$; $m / z: 285 ; m p: 175-176^{\circ} \mathrm{C}$ ) [15] and subsequent sub-frs 6-8 (obtained $n$-hexane- EtOAc 3:7; $2.5: 7.5 ; 2: 8$ ) yielded 1,3 dimethoxy-10-methylacridone $\mathrm{C}_{16} \mathrm{H}_{13} \mathrm{NO}_{3}$ (11; $8.0 \mathrm{mg}$; $m / z: 269 ; \mathrm{mp}: 165^{\circ} \mathrm{C}$ ) [14].

One hundred grams of OSR were partitioned in the water to obtain sequentially hexane fraction (20.1 g), $\mathrm{CH}_{2} \mathrm{Cl}_{2}$ fraction $(24.7 \mathrm{~g})$, acetone fraction $(17.0 \mathrm{~g}$ ) and the $\mathrm{MeOH}$ fraction $(32.5 \mathrm{~g})$. The $\mathrm{CH}_{2} \mathrm{Cl}_{2}$ crude extract (24.7 g) was then submitted to VLC on silica gel (25$40 \mu \mathrm{m}, 8 \mathrm{~cm} \times 60 \mathrm{~cm}, 100 \mathrm{~g})$ and eluted with hexaneethyl acetate gradients: $(8: 2,1.5 \mathrm{~L}),(6: 4,1.5 \mathrm{~L}),(5: 5$, $1.25 \mathrm{~L}),(4: 6,1.25 \mathrm{~L}),(2: 8,1 \mathrm{~L})$ and finally with pure EtOAc $(500 \mathrm{~mL})$ to give 40 fractions of $250 \mathrm{ml}$ each. These fractions were pooled on the basis of their TLC profiles. Fractions 1-17 (10 g), obtained with $80 \%$ hexane-EtOAc were subjected to column chromatography over silica gel $(25-40 \mu \mathrm{m}, 4 \mathrm{~cm} \times 60 \mathrm{~cm}, 65 \mathrm{~g})$ eluting with hexane- $\mathrm{CH}_{2} \mathrm{Cl}_{2}$ with a continuous gradient (95:5 to $7: 3)$ to yield skimmianine $\mathrm{C}_{14} \mathrm{H}_{13} \mathrm{NO}_{4}(12 ; 2.1 \mathrm{mg} ; \mathrm{m} / z$ : 259; mp:176-177 ${ }^{\circ} \mathrm{C}$ ) [16] and kokusaginine $\mathrm{C}_{14} \mathrm{H}_{13} \mathrm{NO}_{4}$ (13; $7.5 \mathrm{mg} ; \mathrm{m} / z$ : 259 ; $\mathrm{mp}: 171^{\circ} \mathrm{C}$ ) [16]. A continuous 
elution by increasing the solvent polarity (6:4 to pure $\mathrm{CH}_{2} \mathrm{Cl}_{2}$ ) yielded four mixtures sub-frs (A-D). Sub-fr B $(2.7 \mathrm{~g})$, showed after examination on TLC precoated plate a mixture of two compounds. This fraction was further purified on silica gel column chromatography $(25-40 \mu \mathrm{m}$; $3 \times 15 \mathrm{~cm}, 15 \mathrm{~g})$ eluting with hexane- $\mathrm{CH}_{2} \mathrm{Cl}_{2}$ with a continuous gradient $(6: 4$ to $3: 7)$ to yield montrifoline $\mathrm{C}_{18} \mathrm{H}_{21} \mathrm{NO}_{6}\left(14 ; 2.7 \mathrm{mg}, \mathrm{m} / \mathrm{z}\right.$ : 347; mp:1190-192 $\left.{ }^{\circ} \mathrm{C}\right)$ [17] and 1-hydroxy-3-methoxy-10-methylacridone $\mathrm{C}_{15} \mathrm{H}_{13} \mathrm{NO}_{3}$ (15; $15.0 \mathrm{mg} ; \mathrm{m} / z$ : 255; mp:164-165; 174-176 $\left.{ }^{\circ} \mathrm{C}\right)$ [18]. Sub-fr C (2.55 g) was then subjected to silica gel column chromatography eluting with hexane- $\mathrm{CH}_{2} \mathrm{Cl}_{2}$ with a continuous gradient $\left(6: 4\right.$ to pure $\left.\mathrm{CH}_{2} \mathrm{Cl}_{2}\right)$ to yield (+/-) syringaresinol $\mathrm{C}_{22} \mathrm{H}_{26} \mathrm{O}_{8}$ (16; $9.2 \mathrm{mg} ; \mathrm{m} / z$ : 418; mp:185$186^{\circ} \mathrm{C}$; mp:1175-176 ${ }^{\circ} \mathrm{C}$ ) [19] whilst combined sub-frs $21-$ 40 (25 g) obtained from the (1:1) to (1:3) hexane-EtOAc mixtures and pure EtOAc were subjected successively to silica gel column chromatography and preparative TLC, eluting with solvent mixtures (hexane- $\mathrm{CH}_{2} \mathrm{Cl}_{2}$-EtOAc) of increasing polarity to yield limonin $\mathrm{C}_{26} \mathrm{H}_{30} \mathrm{O}_{8}$ (17; $12.0 \mathrm{mg} ; \mathrm{m} / z$ : $470 ; \mathrm{mp}: 298^{\circ} \mathrm{C}$ ) [20].

\section{Isolation and identification of compounds from balsamocitrus camerunensis}

One hundred and twenty grams of $\mathrm{BCB}$ were partitioned by dissolving in $\mathrm{CH}_{2} \mathrm{Cl}_{2}$ to give a soluble (42.0 g) and insoluble $(76.5 \mathrm{~g})$ fractions. The $\mathrm{CH}_{2} \mathrm{Cl}_{2}$ soluble fraction was subjected to silica gel VLC $(25-40 \mu \mathrm{m}, 8 \mathrm{~cm} \times$ $60 \mathrm{~cm}, 120 \mathrm{~g}$ ) and eluted with the increasing polarity of $n$-hexane-EtOAc and $\mathrm{MeOH}$ to afford 160 sub-frs of $250 \mathrm{~mL}$ each. These sub-frs were pooled on the basis of TLC analysis into four main fractions (A-D).

Fraction A (12.5 g, combined from sub-frs 1-40) was column chromatographed over silica gel $(25-40 \mu \mathrm{m}, 3.5$ $\mathrm{cm} \times 50.0 \mathrm{~cm}$ ) with $n$-hexane- $\mathrm{CH}_{2} \mathrm{Cl}_{2}$ gradient. A total of 40 new sub-fractions of $100 \mathrm{~mL}$ each were collected and pooled on the basis of the TLC analysis. Sub-fr 5-15 were further column chromatographed over silica gel (25$40 \mu \mathrm{m}, 2.5 \mathrm{~cm} \times 30.0 \mathrm{~cm})$, using $n$-hexane- $\mathrm{CH}_{2} \mathrm{Cl}_{2}(4: 1)$ mixture as eluent to afford compound 7 (99 mg). Sub-frs 16-40 were further chromatographed over silica gel column $(25-40 \mu \mathrm{m}, 2.5 \mathrm{~cm} \times 30.0 \mathrm{~cm})$, eluting with $n$ hexane- $\mathrm{CH}_{2} \mathrm{Cl}_{2}$ (1:1) mixture to yield 1-hydroxy-3,6dimethoxy-8-methylxanthone or lichexanthone $\mathrm{C}_{17} \mathrm{H}_{16} \mathrm{O}_{4}$ (18; $5.2 \mathrm{mg} ; \mathrm{m} / z$ : $284 ; \mathrm{mp}: 187-188^{\circ} \mathrm{C}$ ) [21] and xanthoxyletin $\mathrm{C}_{15} \mathrm{H}_{14} \mathrm{O}_{4}\left(19 ; 7.0 \mathrm{mg} ; \mathrm{m} / z: 258 ; \mathrm{mp}: 133^{\circ} \mathrm{C}\right)$ [22]. Fraction B (10.0 g, combined from the sub-frs $41-$ 79) was purified over silica gel column $(25-40 \mu \mathrm{m}, 3.5 \times$ $50.0 \mathrm{~cm}$ ) with $n$-hexane- $\mathrm{CH}_{2} \mathrm{Cl}_{2}$ gradient. A total of 50 sub-frs of $100 \mathrm{~mL}$ each were collected and pooled on the basis of TLC analysis. Sub-frs 10 to 40 were further purified over silica gel column $(25-40 \mu \mathrm{m}, 2.5 \mathrm{~cm} \times 30.0 \mathrm{~cm})$ with a mixture of $n$-hexane- $\mathrm{CH}_{2} \mathrm{Cl}_{2}(9: 1)$ to yield imperatorin $\mathrm{C}_{16} \mathrm{H}_{14} \mathrm{O}_{4}\left(20 ; 12.0 \mathrm{mg}, \mathrm{m} / \mathrm{z}: 270 ; \mathrm{mp}: 102^{\circ} \mathrm{C}\right)$
[23]. Fraction C (16.5 g, combined from sub-frs 80-110) was purified over silica gel column $(25-40 \mu \mathrm{m}, 3.5 \mathrm{~cm} \times$ $50.0 \mathrm{~cm}$ ) with a Hexane- $\mathrm{CH}_{2} \mathrm{Cl}_{2}$ gradient. A total of 45 fractions of $100 \mathrm{~mL}$ each were collected and combined on the basis of their TLC profile. Fractions 10-25 were further purified over silica gel column $(25-40 \mu \mathrm{m}, 2.5 \mathrm{~cm} \times$ $30.0 \mathrm{~cm}$ ) with $\mathrm{CH}_{2} \mathrm{Cl}_{2}$-acetone (4: 1) mixture to afford scoparone $\mathrm{C}_{11} \mathrm{H}_{10} \mathrm{O}_{4}\left(21 ; 8.7 \mathrm{mg} ; \mathrm{m} / z\right.$ : $\left.206 ; \mathrm{mp}: 144^{\circ} \mathrm{C}\right)$ [24]. Fraction D was further chromatographed on silica gel column, using $\mathrm{CH}_{2} \mathrm{Cl}_{2}$-acetone mixture as eluent, then the recrystallization in $\mathrm{CH}_{2} \mathrm{Cl}_{2}$-acetone (6:4) gave umbelliferone $\mathrm{C}_{9} \mathrm{H}_{6} \mathrm{O}_{3}$ (22; $11.0 \mathrm{mg} ; \mathrm{m} / z$ : 162; mp:230-232 ${ }^{\circ} \mathrm{C}$ ) [25].

\section{Chemicals for antibacterial assay}

Chloramphenicol (Sigma-Aldrich, St. Quentin Fallavier, France) was used as reference antibiotics (RA) against Gram-negative bacteria. $p$-Iodonitrotetrazolium chloride (INT, Sigma-Aldrich) was used as microbial growth indicator [26,27]. Isoniazid (INH) (Sigma) was used as RA against $M$. tuberculosis.

\section{Antibacterial assays \\ Microbial strains and culture media}

The studied microorganisms included reference and clinical strains (Tables 1 and 2) of Escherichia coli, Enterobacter aerogenes, Klebsiella pneumoniae, Providencia stuartii, Pseudomonas aeruginosa, a drug-susceptible strain of $M$. tuberculosis H37Rv obtained from the American Type Culture Collection, and two clinical strains of $M$. tuberculosis MTCS1, MTCS2. M. tuberculosis was plated on Löwenstein-Jensen medium and allowed to grow for 3-4 weeks at $37^{\circ} \mathrm{C}$. Middlebrook $7 \mathrm{H} 9$ broth supplemented with $0.2 \%$ glycerol and $10 \%$ Oleic Acid-Albumin-DextroseCatalase (OADC) (Sigma) was used to determine the MIC and $\mathrm{MBC}$ values of the test samples on $M$. tuberculosis. We previously reported the features [28] of all the tested Gramnegative bacteria. Nutrient agar was used for the activation of bacteria other than M. tuberculosis strains [28]. The clinical strains used in this work are our laboratory collection previously obtained from Yaoundé General Hospital (Cameroon), and from the Mediterranean University (Marseille, France).

\section{INT colorimetric assay for MIC and MBC determinations}

The MIC determinations on Gram-negative bacteria were conducted using rapid INT colorimetric assay according to previously described methods [26,27] with some modifications. The test samples and RA were first of all dissolved in DMSO/Mueller Hinton Broth (MHB) or DMSO/7H9 broth. The final concentration of DMSO was lower than $2.5 \%$ and does not affect the microbial growth [29]. The solution obtained was then added to $\mathrm{MHB}$, and serially diluted two fold (in a 96- wells microplate). Then, $100 \mu \mathrm{l}$ of inoculum $1.5 \times 10^{6} \mathrm{CFU} / \mathrm{ml}$ 
Table 1 MICs of the extracts, compounds from Garcinia nobilis, Oricia suaveolens, Balsmocitrus camerunensis and reference drugs on documented strains and clinical MDR isolates

\begin{tabular}{|c|c|c|c|c|c|c|c|c|c|c|c|c|c|c|c|}
\hline \multirow{3}{*}{$\begin{array}{l}\text { Tested } \\
\text { samples }^{a}\end{array}$} & \multicolumn{15}{|c|}{ Microorganisms, strains and MIC $(\mu \mathrm{g} / \mathrm{ml})^{\mathrm{b}}$} \\
\hline & \multicolumn{3}{|c|}{ E. coli } & \multicolumn{3}{|c|}{ E. aerogenes } & \multicolumn{2}{|c|}{ K. pneumoniae } & \multicolumn{2}{|c|}{ P. stuartii } & \multicolumn{2}{|c|}{ P. aeruginosa } & \multicolumn{3}{|c|}{ M. tuberculosis } \\
\hline & ATCC 10536 & AG 100 & AG 102 & ATCC 13048 & CM 64 & $E A 27$ & ATCC 11296 & KP55 & ATCC 29916 & NAE 16 & PA 01 & PA 124 & ATCC 27294 & MTCS1 & MTCS2 \\
\hline \multicolumn{16}{|c|}{ Crude extracts } \\
\hline GNB & $\underline{64}$ & 256 & 256 & 256 & 512 & 256 & 128 & 512 & 512 & - & 512 & - & 128 & 256 & 256 \\
\hline OSR & 128 & 512 & - & 512 & - & - & 256 & 256 & 512 & 256 & - & - & 512 & - & 512 \\
\hline OSW & 128 & 512 & - & - & - & - & 128 & 128 & - & 128 & - & - & 256 & - & 512 \\
\hline $\mathrm{BCB}$ & 512 & - & - & 256 & - & - & 512 & 512 & - & - & - & - & - & - & - \\
\hline \multicolumn{16}{|c|}{ Compounds } \\
\hline 1 & 256 & 128 & - & - & - & - & - & - & - & - & - & - & - & - & - \\
\hline 2 & 64 & 64 & 128 & 128 & 256 & 64 & 512 & 512 & 256 & 64 & 64 & 128 & $\underline{8}$ & 32 & $\underline{8}$ \\
\hline 3 & 128 & 128 & 64 & 256 & - & 256 & - & - & - & - & - & - & 64 & - & 128 \\
\hline 4 & - & 64 & 128 & - & 256 & 128 & - & - & - & - & 256 & - & 512 & - & 512 \\
\hline 5 & 64 & 128 & 128 & - & - & 512 & 512 & - & 512 & - & 64 & 128 & 32 & 64 & 64 \\
\hline 8 & 512 & 128 & 256 & - & 512 & 128 & 512 & - & - & - & - & - & 128 & 512 & 256 \\
\hline 9 & - & 128 & 256 & - & 256 & 256 & - & - & - & - & - & - & - & - & - \\
\hline 10 & 64 & 128 & 256 & - & - & 128 & - & - & 512 & - & - & - & 128 & - & 512 \\
\hline 11 & 128 & 256 & 128 & - & 256 & 512 & 512 & - & - & - & - & 512 & - & - & - \\
\hline 13 & 512 & 64 & 256 & - & 512 & 128 & 256 & - & - & - & 128 & 512 & 256 & 512 & 512 \\
\hline 15 & 128 & 256 & 256 & - & - & 256 & - & - & - & - & - & - & - & - & - \\
\hline 16 & 128 & 128 & - & - & & 512 & - & - & 512 & - & - & - & 512 & - & - \\
\hline 17 & - & 128 & - & - & - & - & - & - & - & - & - & - & - & - & - \\
\hline 18 & - & 256 & - & - & - & 256 & - & - & - & 256 & - & - & - & - & - \\
\hline 19 & - & 256 & - & - & - & - & - & - & - & - & - & - & - & - & - \\
\hline 20 & - & 512 & - & - & - & - & - & - & - & - & - & - & - & - & - \\
\hline 21 & 512 & 256 & - & - & - & 256 & 256 & - & - & - & - & - & - & - & - \\
\hline 22 & 512 & 256 & 256 & 512 & 128 & - & - & 512 & - & - & - & - & - & - & - \\
\hline RA & $<4$ & 16 & 512 & 64 & - & 64 & 4 & 32 & - & 64 & 128 & 128 & 1 & 128 & 4 \\
\hline
\end{tabular}

a Tested samples [methanol-dichloromethane 1:1 extract of the stem bark of Garcinia nobilis (GNB), the wood (OSW)roots (OSR) of Oricia suaveolens, and stem bark of Balsmocitrus camerunensis (BCB); compounds isolated from the stem bark of Garcinia nobilis (1-5), Oricia suaveolens woods (6-11) and roots (12-17), and the stem back of Balsmocitrus camerunensis (18-22); caroxanthone (1), 4-prenyl-2-(3,7-dimethyl-2,6octadienyl)-1,3,5,8-tetrahydroxyxanthone (2), smeathxanthone A (3), 8-hydroxycudraxanthone G (4), morusignin I (5), stigma-5-en-3-ol (6), 20(29)lupen-2-ol (7), evoxanthine (8), norevoxanthine (9), 1-hydoxy-2,3-

dimethoxy-10-methylacridone (10), 1,3-dimethoxy-10-methylacridone (11), kokusaginine (13), 1-hydroxy-4-methoxy-10-methylacridone (15), syringaresinol (16), limonin (17), 1-hydroxy-3,6-dimethoxy-8-methylxanthone (18), xanthoxyletin (19), imperatorin (20), 6,8-dimethoxycoumarin (21), umbelliferone (22)]; RA: reference antibiotics were chloramphenicol for bacteria, isoniazid for $M$. tuberculosis; ${ }^{b}(-)$ : $M I C>512 \mu \mathrm{g} / \mathrm{mL}$. 
Table 2 MBCs of the extracts, compounds from Garcinia nobilis, Oricia suaveolens, Balsmocitrus camerunensis and reference drugs on documented strains and clinical MDR isolates

\begin{tabular}{|c|c|c|c|c|c|c|c|c|c|c|c|c|c|c|c|}
\hline \multirow{3}{*}{$\begin{array}{l}\text { Tested } \\
\text { samples }^{\mathrm{a}}\end{array}$} & \multicolumn{15}{|c|}{ Microorganisms, strains and MBC $(\mu \mathrm{g} / \mathrm{ml})^{\mathrm{b}}$} \\
\hline & \multicolumn{3}{|c|}{ E. coli } & \multicolumn{3}{|c|}{ E. aerogenes } & \multicolumn{2}{|c|}{ K. pneumoniae } & \multicolumn{2}{|c|}{ P. stuartii } & \multicolumn{2}{|c|}{ P. aeruginosa } & \multicolumn{3}{|c|}{ M. tuberculosis } \\
\hline & ATCC 10536 & AG 100 & AG 102 & ATCC 13048 & CM 64 & $E A 27$ & ATCC 11296 & KP55 & ATCC 29916 & NAE 16 & PA 01 & PA 124 & ATCC 27294 & MTCS1 & MTCS2 \\
\hline \multicolumn{16}{|c|}{ Crude extracts } \\
\hline$\overline{\text { GNB }}$ & 256 & 512 & $>512$ & $>512$ & $>512$ & $>512$ & 256 & $>512$ & $>512$ & - & $>512$ & - & 256 & $>512$ & 512 \\
\hline OSR & 256 & $>512$ & - & $>512$ & - & - & 512 & 512 & $>512$ & 512 & - & - & $>512$ & - & $>512$ \\
\hline OSW & 512 & $>512$ & - & - & - & - & 256 & 512 & - & 512 & - & - & 512 & - & $>512$ \\
\hline $\mathrm{BCB}$ & $>512$ & - & - & 512 & - & - & $>512$ & $>512$ & - & - & - & - & - & - & - \\
\hline \multicolumn{16}{|c|}{ Compounds } \\
\hline 1 & $>512$ & $>512$ & - & - & - & - & - & - & - & - & - & - & - & - & - \\
\hline 2 & 128 & 256 & 256 & 256 & $>512$ & 128 & $>512$ & $>512$ & 512 & 128 & 128 & 256 & 16 & 64 & 32 \\
\hline 3 & 256 & 256 & 128 & 512 & - & 512 & - & - & - & - & - & - & 128 & - & 256 \\
\hline 4 & - & 128 & 256 & - & 512 & 256 & - & - & - & - & 512 & - & $>512$ & - & $>512$ \\
\hline 5 & 128 & 256 & 256 & - & - & $>512$ & $>512$ & - & $>512$ & - & 128 & 256 & 64 & 128 & 128 \\
\hline 8 & $>512$ & 256 & $>512$ & - & $>512$ & 256 & $>512$ & - & - & - & - & - & 256 & $>512$ & 512 \\
\hline 9 & - & 256 & $>512$ & - & 512 & $>512$ & 256 & - & - & - & - & - & - & - & - \\
\hline 10 & 256 & 256 & 512 & - & - & - & - & - & $>512$ & - & - & - & 512 & - & $>512$ \\
\hline 11 & $>512$ & - & - & - & - & $>512$ & - & - & - & - & - & - & - & - & - \\
\hline 13 & $>512$ & 128 & 512 & - & $>512$ & 256 & 512 & - & - & - & 256 & $>512$ & 512 & $>512$ & $>512$ \\
\hline 15 & 256 & 512 & $>512$ & - & - & 512 & - & - & - & - & - & - & - & - & - \\
\hline 16 & 256 & 256 & - & - & . & $>512$ & - & - & $>512$ & - & - & - & $>512$ & - & - \\
\hline 17 & - & 256 & - & - & - & - & - & - & - & - & - & - & - & - & - \\
\hline 18 & - & 512 & - & - & - & 512 & - & - & - & 512 & - & - & - & - & - \\
\hline 19 & - & 512 & - & - & - & - & - & - & - & - & - & - & - & - & - \\
\hline 20 & - & $>512$ & - & - & - & - & - & - & - & - & - & - & - & - & - \\
\hline 21 & $>512$ & 512 & - & - & - & 512 & 512 & - & - & - & - & - & - & - & - \\
\hline 22 & $>512$ & 512 & 512 & $>512$ & 256 & - & - & $>512$ & - & - & - & - & - & - & - \\
\hline $\mathrm{RA}$ & $<4$ & 32 & $>512$ & 128 & - & 128 & 8 & 64 & - & 128 & 256 & 256 & 2 & 256 & 16 \\
\hline
\end{tabular}

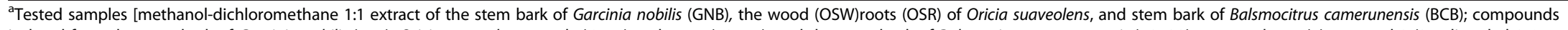
isolated from the stem bark of Garcinia nobilis (1-5), Oricia suaveolens woods (6-11) and roots (12-17), and the stem back of Balsmocitrus camerunensis (18-22); caroxanthone (1), 4-prenyl-2-(3,7-dimethyl-2,6-

octadienyl)-1,3,5,8-tetrahydroxyxanthone (2), smeathxanthone A (3), 8-hydroxycudraxanthone G (4), morusignin I (5), stigma-5-en-3-ol (6), 20(29)lupen-2-ol (7), evoxanthine (8), norevoxanthine (9), 1-hydoxy-2,3-

dimethoxy-10-methylacridone (10), 1,3-dimethoxy-10-methylacridone (11), kokusaginine (13), 1-hydroxy-4-methoxy-10-methylacridone (15), syringaresinol (16), limonin (17), 1-hydroxy-3,6-dimethoxy-8-methylxanthone

(18), xanthoxyletin (19), imperatorin (20), 6,8-dimethoxycoumarin (21), umbelliferone (22)]; RA: reference antibiotics were chloramphenicol for bacteria, isoniazid for M. tuberculosis; ${ }^{b}(-)$ : MBC not determined as the MIC

was above $512 \mu \mathrm{g} / \mathrm{ml}$. 
prepared in appropriate broth was added [30]. The plates were covered with a sterile plate sealer, then agitated to mix the contents of the wells using a plate shaker and incubated at $37^{\circ} \mathrm{C}$ for $18 \mathrm{~h}$. The assay was repeated thrice. Wells containing adequate broth, $100 \mu \mathrm{l}$ of inoculum and DMSO to a final concentration of $2.5 \%$ served as negative control. The MIC of samples was detected after $18 \mathrm{~h}$ incubation at $37^{\circ} \mathrm{C}$, following addition $(40 \mu \mathrm{l})$ of $0.2 \mathrm{mg} / \mathrm{ml} \mathrm{INT}$ and incubation at $37^{\circ} \mathrm{C}$ for 30 minutes. Viable bacteria reduced the yellow dye to a pink. MIC was defined as the sample concentration that prevented this change and exhibited complete inhibition of microbial growth. The MBC was determined by adding $50 \mu \mathrm{l}$ aliquots of the preparations, which did not show any growth after incubation during MIC assays, to $150 \mu \mathrm{l}$ of adequate broth. These preparations were incubated at $37^{\circ} \mathrm{C}$ for $48 \mathrm{~h}$. The $\mathrm{MBC}$ was regarded as the lowest concentration of extract, which did not produce a color change after addition of INT as mentioned above [30,31].

\section{Microplate Alamar blue assay (MABA) against M. Tuberculosis}

The activity of all samples against $M$. tuberculosis strains was tested using the MABA [32]. Briefly, each of the above $M$. tuberculosis strains was cultured at $37^{\circ} \mathrm{C}$ in Middlebrook $7 \mathrm{H} 9$ broth supplemented with $0.2 \%$ glycerol and 10\% OADC (oleic acid-albumin-dextrosecatalase; Sigma) until logarithmic growth was reached. The homogenous culture was obtained using sterile glass beads and vortex. About $6 \times 10^{6} \mathrm{CFU} / \mathrm{ml}$ inoculum $(100 \mu \mathrm{l})$ of $M$. tuberculosis was then added to the two fold serially diluted samples $(100 \mu \mathrm{l})$. The final concentration of DMSO in all assays was $2.5 \%$ or less and this dilution also served as solvent control. The samples were assayed in triplicate. All tests were carried out in sterile flat-bottomed 96-well microplates. Each microplate was incubated for 5 days at $37^{\circ} \mathrm{C}$ in a sealed plastic $\mathrm{CO}_{2}$-permeable bag. After 5 days of incubation, $32 \mu \mathrm{l}$ of a mixture of freshly prepared Alamar Blue solution and 20\% sterile Tween-80 (Sigma) 1:1 v/v were added to one growth-control well. The microplates were incubated again at $37^{\circ} \mathrm{C}$ for $24 \mathrm{~h}$. If a color shift from blue to pink was observed in the growth-control sample, $32 \mu \mathrm{l}$ of alamar blue solution was added to each of the remaining wells, and the microplate was further incubated for $24 \mathrm{~h}$. A well-defined pink color was interpreted as positive bacterial growth, whereas a blue color indicated an absence of growth. The MIC corresponded to the greatest dilution of sample extract in which the color shift from blue to pink was not observed.

Samples with recorded MIC values following MABA were assayed for their mycobactericidal effect [32]. Briefly, $5 \mu \mathrm{l}$ of the undeveloped mycobacterial suspensions were transferred from the former to a new microplate containing $195 \mu \mathrm{l}$ of fresh culture medium per well. Three wells were inoculated with $100 \mu \mathrm{l}$ of fresh inoculum as for MABA and three more wells were incubated with $200 \mu \mathrm{l}$ of culture medium only, as negative controls. The microplates were incubated and developed with alamar blue as for MABA. The MBC corresponded to the minimum sample concentration that did not cause a color shift in cultures that were re-incubated in fresh medium.

\section{Results and discussion}

The chemical structures of the compounds isolated from G. nobilis, O. suaveolens and B. camerunensis (Figure 1) were established by spectroscopic methods. The compounds were isolated from the stem bark of G. nobilis (1-5), the woods of O. suaveolens (6-11), the roots (12-17) and the stem bark of B. camerunensis $(7,18-22)$. The twenty two isolated compounds were identified as caroxanthone (1), 4-prenyl-2-(3,7-dimethyl-2,6-octadienyl)1,3,5,8-tetrahydroxyxanthone (2), smeathxanthone A (3), 8-hydroxycudraxanthone G (4), morusignin I (5), stigma-5en-3-ol (6), lupeol (7), evoxanthine (8), norevoxanthine (9), 1-hydoxy-2,3-dimethoxy-10-methylacridone(10), 1,3-dime thoxy-10-methylacridone (11), skimmianine (12), koku saginine (13), montrifoline (14), 1-hydroxy-4-methoxy10-methylacridone (15), syringaresinol (16), limonin (17), 1-hydroxy-3,6-dimethoxy-8-methylxanthone (18), xantho xyletin (19), imperatorin (20), scoparone (21) and umbe lliferone (22) [11-25]. Amongst the twenty-two compounds were three terpenoids $(6,7$ and 17$)$, eleven phenolic compounds $(\mathbf{1}-5, \mathbf{1 6}, \mathbf{1 8 - 2 2})$, and eight alkaloids (10-17). The isolated terpenoids were steroid (6), triterpenoid (7), and limonoid (17) whilst the alkaloids included five acridones $(\mathbf{8}-\mathbf{1 1}, \mathbf{1 5})$ and three furanoquinolines (12-14). The phenolics obtained herein were six xanthones $(\mathbf{1 - 5}, \mathbf{1 8})$, one lignan (16) and four coumarins (19-22). The isolation and identification of compounds 1-5 from G. nobilis was previously reported [10]. The occurrence of alkaloids and terpernoids from O. suaveolens was reported $[5,6]$, and their isolation in the present study is in consistence with previous reports. The occurrence of coumarins, quinoline alkaloids, and free aliphatic acids was also reported in B. camerunensis [9]. However, in this study, only coumarins were isolated. The crude extracts as well as the isolated compounds [excluding compounds 6, 7, 12 (known to have low or no antimicrobial activity), and $\mathbf{1 4}$ (isolated in very low quantities)] were tested for the antibacterial activities against Gram-negative bacteria and $M$. tuberculosis and the results are summarized in Tables 1 and 2 .

The results of the MIC determinations (Table 1) showed that the crude extract from G. nobilis (GNB) was the most active amongst the studied extracts, its inhibitory effects being noted on 12 of the 14 tested bacteria. GNB also 
exhibited the best activity against $M$. tuberculosis ATCC 27294 (MIC of $128 \mu \mathrm{g} / \mathrm{ml}$ ) and E. coli ATCC10536 (MIC of $64 \mu \mathrm{g} / \mathrm{ml}$ ) than OSR, OSW and BCB. The inhibitory effects of the extracts OSR and OSW from O. suaveolens were noted on $9 / 14$ and 7/14 studied bacteria respectively, meanwhile that of the extract $\mathrm{BCB}$ of $B$. camerunensis was observed on 4/14 pathogens tested. Interestingly, compound 2 isolated from the most active extract GNB, also exhibited the best activity, preventing the growth of all the fourteen tested microorganisms. The lowest MIC obtained with compound 2 was $8 \mu \mathrm{g} / \mathrm{ml}$ against $M$. tuberculosis ATCC 27294 and the clinical MTCS2 strains. It is noteworthy that compound $\mathbf{2}$ was more active than chloramphenicol on two Gram-negative MDR bacteria, namely $E$. coli AG102 and E. aerogenes CM64 (Table 1). Other compounds showed selective activities, their effects being noted on 1/14 tested bacteria for compounds 16, 17, 19 and $20 ; 2 / 14$ for $1 ; 3 / 14$ for $18 ; 4 / 14$ for 9 and $21 ; 5 / 14$ for 22; 7/14 for 3, 4, 10 and 11; 9/14 for 8 ; and 11/14 for 5 and 13. The results of the MBC determinations (Table 2) also showed the activities of the studied samples on some of the tested microorganisms. As observed with MIC data (Table 1), the lowest MBC value (Table 2) was recorded with compound $2(16 \mu \mathrm{g} / \mathrm{ml})$ against $M$. tuberculosis ATCC 27294.

Phytochemicals are routinely classified as antimicrobials on the basis of susceptibility tests that produce MIC in the range of 100 to $1000 \mu \mathrm{g} / \mathrm{ml}$ [33]. The activity is considered to be significant if MIC values are below $100 \mu \mathrm{g} / \mathrm{ml}$ for crude extract and moderate when the MICs vary from 100 to $625 \mu \mathrm{g} / \mathrm{ml}[34,35]$. Also, the activity of compounds is considered to be significant when the MIC is below $10 \mu \mathrm{g} / \mathrm{ml}$, and moderate when such values vary between 10 and $100 \mu \mathrm{g} / \mathrm{ml}[34,35]$. On the basis of such criteria, the activity of the studied crude extracts can mostly be considered as moderate, though a significant effect was observed with GNB on E. coli ATCC strains. Compound $\mathbf{2}$ was significantly active against M. tuberculosis ATCC 27294 and MTCS2 strains. However its activities can also be considered as moderate against the majority of the bacteria tested. All the tested compounds were active on at least one of the studied microorganisms, and their presence can explain the activity of the crude extracts. Nonetheless, it can be observed that the activity of GNB was not detected on both P. stuartii ATCC NAE16 and P. aeruginosa PA124, while the extract yielded at least one active compound on these bacteria (Table 1). This can be explained by the fact that the activity of the crude extract does not only depend on the presence of the active compounds, but is also influenced by the quantity and/or possible interaction with other constituents of the plant. This observation can also be applied when carefully analysing the activities of the crude extracts from $O$. suaveolens and $B$. camerunensis and their constituents (Table 1). The activity of the crude extracts and compounds studied herein (and mostly compound 2) can be considered interesting when regarding the medical importance of the studied bacteria. In fact, the clinical MDR Gram-negative bacteria tested express active efflux pumps and are involved in many therapeutic failures [28]. To the best of our knowledge, the antibacterial activities of the extracts of G. nobilis, O. suaveolens and B. camerunensis as well as those of most of the studied compounds are being reported for the first time. Nevertheless, some of the isolated compounds were reported for their antibacterial properties. In effect, lupeol (7) is known to have low antibacterial activities, the lowest MIC value obtained against Enterococcus faecalis ATCC 29212 being $63 \mu \mathrm{g} /$ $\mathrm{ml}$ [36]. The activity of compound 7 was also not detected against the sensitive Mycobacterium smegmatis when it was tested at a concentration up to $312 \mu \mathrm{g} / \mathrm{ml}$ [37] and consequently, this compound was not tested again in this work. Previously we also reported the moderate activity of the alkaloid $\mathbf{1 3}$ on some sensitive Gramnegative bacteria as well as it low effect against $M$. smegmatis [37]. This compound was not more active against MDR bacteria as observed in the present work, confirming its low antibacterial potential. It has also been demonstrated that compounds 3 (active only on two of 21 tested microorganisms) [38] and $\mathbf{1 6}$ (inhibition zone diameters for $10 \mu \mathrm{l}$ discs at $10^{4} \mathrm{ppm}$ reported as $0.0 ; 0.2 ; 0.4$ and $0.5 \mathrm{~mm}$ against $K$. pneumoniae, S. aureus, Pseudomonas syringae and Bacillus subtilis respectively) [39] have low antibacterial activities. Such reports are in accordance with the results obtained in the present study.

Though compounds 17 (limonin) and 20 (imperatonin) showed poor activities as reported herein, their antilisterial inhibitory effects were found moderate, the MIC values obtained against five Listeria monocytogenes ATCC strains varying between $15.62-31.25 \mu \mathrm{g} / \mathrm{ml}$ [40].

Compounds 19 (xanthoxyletin) and 22 (umbelliferone) were also found inactive against $M$. tuberculosis and poorly active against Gram-negative bacteria, consolidating the previously reported data [41,42]. It is noteworthy that compound 12 was reported not to have any bacterial activity [43] and was not tested in the present work.

When regarding the structure-activity relationship, it appears that coumarins had the lowest activities, none of them been active against $M$. tuberculosis. The tested tetranortriterpenoid, compound $\mathbf{1 7}$ also showed very weak antibacterial activities. These results are in consistence with previous studies, showing the low antibacterial activities of terpenoids and coumarins against bacteria expressing MDR phenotype [2]. Alkaloids also showed low antibacterial activities. However moderate inhibitory effects were noted with 10 (1-hydoxy-2,3-dimethoxy-10methylacridone) and $\mathbf{1 3}$ (kokusaginine) respectively 
against E. coli ATTC and AG100 strains (Table 1). Amongst alkaloids, compound 13, one of the three isolated furanoquinolines, showed the best spectrum of activity (contrary to the five acridone alkaloids) and was found active on both M. tuberculosis and Gram-negative bacteria. Within the acridone alkaloids, and when comparing the effects of compounds $\mathbf{1 0}$ and $\mathbf{1 5}$ [antibacterial spectra $(7 / 14$ of the tested bacteria for 10 and $4 / 14$ for 15); lowest MIC value $(64 \mu \mathrm{g} / \mathrm{ml}$ for 10 and $128 \mu \mathrm{g} / \mathrm{ml}$ for 15)], it appears that the presence of methoxyl$\left(-\mathrm{OCH}_{3}\right)$ group in $\mathrm{C} 2$ (compound 10) increases the bacterial susceptibility (Figure 1, Table 1). A comparison of the activities of compounds $\mathbf{8}$ and $\mathbf{9}$ [the presence of $\mathrm{OCH}_{3}$ group in $\mathrm{C} 1$ (compound 8) instead of - $\mathrm{OH}$ group (compound 9)] on one hand, and those of $\mathbf{1 1}$ and $\mathbf{1 5}$ [the presence of $-\mathrm{OCH}_{3}$ group in $\mathrm{C} 1$ (compound 11) instead of the hydroxyl $(-\mathrm{OH})$ group (compound 15)] on another hand seems to confirm the fact that the natural substitution of $-\mathrm{OCH}_{3}$ by $-\mathrm{OH}$ in the studied alkaloids increases their activities (Figure 1, Table 1). The best antibacterial activities were recorded with xanthones. Within the studied xanthones and when regarding the activities of compounds $\mathbf{2}$ and $\mathbf{3}$, it appears that the presence of additional prenyl- group in C4 significantly increases the antibacterial activity (Figure 1, Table 1). Between compounds $\mathbf{4}$ and $\mathbf{5}$, it can also be deduced that the cyclisation increase the activity (Figure 1, Table 1).

\section{Conclusion}

The results of the present investigation are important, in regards to the medical importance of the studied microorganisms. Hence, these data provide evidence that some of the constituents of G. nobilis, O. suaveolens and B. camerunensis and mostly compound $\mathbf{2}$ (isolated from G. nobilis), as well as some of the crude extracts from the three plants could be potential antimicrobial products to fight MDR bacteria. The combination of the three plants as used locally in the treatment of infections will further be investigated to provide better understanding to the traditional use.

\section{Competing interests}

The authors declare that they have no competing interests.

\section{Authors' contributions}

HF, ATM and VK carried out the study; HF and VK wrote the manuscript; VK, AEN, CDM, SF, MIC, JJMM and NL supervised the work. All authors read and approved the final manuscript.

\section{Acknowledgements}

Authors are thankful to the Cameroon National Herbarium (Yaoundé) for the plant identification. Authors are also grateful to the International Foundation for Science (IFS-Grant F/4579-2 to VK), TWAS for financial support for ICCBSTWAS fellowship at the H.E.J. Research Institute of Chemistry, International Center of Chemical Sciences, University of Karachi, Pakistan on year 2010 (HF). Authors are also thankful to UMR-MD1 (Mediterranean University, Marseille, France) for providing some clinical bacteria.

\section{Author details}

${ }^{1}$ Department of Organic Chemistry, Faculty of Science, University of Yaoundé 1, Po.box 812, Yaoundé, Cameroon. ²Department of Biochemistry, Faculty of Science, University of Dschang, Dschang, Cameroon. ${ }^{3}$ Department of Organic Chemistry, Higher Teachers Training College, University of Maroua, P.O.Box 46, Maroua, Cameroon. ${ }^{4} \mathrm{H}$. E. J. Research Institute of Chemistry, International Center for Chemical and Biological Sciences, University of Karachi, Karachi 75270, Pakistan. ${ }^{5}$ Department of Plant Science, Faculty of Agricultural and Biological Science, Pretoria 0002, South Africa.

Received: 16 August 2012 Accepted: 8 April 2013

Published: 10 April 2013

\section{References}

1. Kuete V, Ngameni B, Tangmouo JG, Bolla JM, Alibert-Franco S, Ngadjui BT, Pagès JM: Efflux pumps are involved in the defense of Gram-negative bacteria against the natural products isobavachalcone and diospyrone. Antimicrob Agents Chemother 2010, 54:1749-1752.

2. Kuete $V$, Alibert-Franco $S$, Eyong KO, Ngameni B, Folefoc GN, Nguemeving JR, Tangmouo JG, Fotso GW, Komguem J, Ouahouo BM, Bolla JM, Chevalier J, Ngadjui BT, Nkengfack AE, Pagès JM: Antibacterial activity of some natural products against bacteria expressing a multidrug-resistant phenotype. Int J Antimicrob Agents 2011, 37:156-161.

3. Ampofo AS, Waterman GP: Xanthones from three Garcinia species. Phytochemistry 1986, 25:2351-2355.

4. Nguyen LH, Venkatraman G, Sim KY, Harrison L: Xanthones and benzophenones from Garcinia griffithii and Garcinia mangostana. Phytochemistry 2005, 66:1718-1723.

5. Abe MO: The occurrence of the alkaloid oricine in the wood of Oricia suaveolens. Phytochemistry 1971, 10:3328-3330.

6. Abe MO, Taylor DAH: A quinolone alkaloid from Oricia suaveolens. Phytochemistry 1971, 10:1167-1169.

7. Letouzey R: Flore du Cameroun No. 1. Rutacées, Zygophyllacées, Balanitacées. Paris: Museum National d'Histoire Naturelle; 1963.

8. Tsassi VB, Hidayat H, Meffo BY, Kouam SF, Dongo E, Schulz B, Green IR, Krohn K: Anti-microbial coumarins from the stem bark of Afraegle paniculata. Nat Prod Commun 2010, 5:559-561.

9. Asase A, Oteng-Yeboah AA, Odamtten GT, Simmonds MSJ: Ethnobotanical study of some Ghanaian anti-malarial plants. J Ethnopharmacol 2005, 99:273-279.

10. Fouotsa H, Meli Lannang L, Djama Mbazoa C, Rasheed S, Marasini BP, Ali Z, Devkota KP, Kengfack AE, Shaheen F, Choudhary MI, Sewald N: Xanthones inhibitors of a-glucosidase and glycation from Garcinia nobilis. Phytochem Lett 2012, 5:236-239.

11. Gella MD, Monako P, Previtera L: Stigmasterols from Typha latifolia. J Nat Prod 1990, 53:1430-1435.

12. Sholichin M, Yamasaki K, Kasai $\mathrm{R}$, Tanaka O: ${ }^{13} \mathrm{C}$ Nuclear Resonance of lupane-type triterpenes, lupeol, betulin and betulinic acid. Chem Pharm Bull 1980, 28:1006-1008.

13. Govindachari TR, Pai BR, Subramaniam PS, Subramanyam V: A synthesis of evoxanthine. Tetrahedron 1967, 23:1827-1829.

14. Ermias D, Abiy Y, Peter GW, Alexander IG: The chemical systematics of the Rutaceae, subfamily Toddalioideae, in Africa. Biochem Syst Ecol 1988, 16:179-188.

15. Vaquette J: Alkaloids from leave of Teclea boiviniaana. Planta Med 1978 60:78-84.

16. Al-Rehaily AJ, Ahmad MS, Muhammad I, Al-Thukair AA, Perzanowski HP. Furoquinoline alkaloids from Teclea nobilis. Phytochemistry 2003, 64:1405-1411.

17. Wondimu A, Dagne E, Waterman PG: Quinoline alkaloids from the leaves of Teclea simplicifolia. Phytochemistry 1988, 27:959-960.

18. Kuzovkina I, Al'terman I, Schneider B: Specific accumulation and revised structures of acridone alkaloid glucosides in the tips of transformed roots of Ruta graveolens. Phytochemistry 2004, 65:1095-1100.

19. Semwal S, Sharma RK: A new lignan rhamnoside from Bauhinia retusa seed pods (Caesalpiniaceae). Chinese Chem Lett 2011, 22:1081-1083.

20. Barton DHR, Pradhan SK, Sternhell S, Templton JF: T: Part XXV: The constitutions of limonin and related bitter principles. $J$ Chem Soc 1961:255-275

21. Chaurasia N, Wichtl M: Sterols and Steryl Glycosides from Urtica dioica. J Nat Prod 1987, 50:881-885. 
22. Lin $L C$, Yang $L L$, Chou CJ: Cytotoxic naphthoquinones and plumbagic acid glucosides from Plumbago zeylanica. Phytochemistry 2003, 62:619-622.

23. Renmin L, Aifeng L, Ailing S: Preparative isolation and purification of coumarins from Angelica dahurica (Fisch. ex Hoffm) Benth, et Hook. $f$ (Chinese traditional medicinal herb) by high-speed counter-current chromatography. J Chromatograph A 2004, 1052:223-227.

24. Ulubelen A, Oksuz S, Aynehchi Y: Salehi Sormaghi MH, Souri A, Mabry TM: Capillarin and Scaporone from Artemisia lamprocaulos. J Nat Prod 1984, 47:170-171.

25. Shouce ZYC: The Committee of Chinese Herb Information. Beijing: Renmin Weisheng Publisher; 1986.

26. Eloff JN: A sensitive and quick microplate method to determine the minimal inhibitory concentration of plant extracts for bacteria. Planta Med 1998, 64:711-713.

27. Mativandlela SPN, Lall N, Meyer JJM: Antibacterial, antifungal and antitubercular activity of (the roots of) Pelargonium reniforme (CURT) and Pelargonium sidoides (DC) (Geraniaceae) root. S Afr J Bot 2006, 72:232-237.

28. Lacmata ST, Kuete V, Dzoyem JP, Tankeo SB, Teke GN, Kuiate JR, Pages JM: Antibacterial Activities of Selected Cameroonian Plants and Their Synergistic Effects with Antibiotics against Bacteria Expressing MDR Phenotypes. Evid Based Complement Alternat Med 2012, 2012:623723.

29. Kuete V, Ngameni B, Fotso Simo CC, Kengap Tankeu R, Tchaleu Ngadjui B, Meyer JJM, Lall N, Kuiate JR: Antimicrobial activity of the crude extracts and compounds from Ficus chlamydocarpa and Ficus cordata (Moraceae). J Ethnopharmacol 2008, 120:17-24.

30. Tereschuk ML, Riera MVQ, Castro GR, Abdala LR: Antimicrobial activity of flavonoid from leaves of Tagetes minuta. J Ethnopharmacol 1997, 56:227-232.

31. Zgoda JR, Porter JR: A convenient microdilution method screening natural products against bacteria and fungi. Pharmaceut Biol 2001, 39:221-225.

32. Jimenez-Arellanes A, Meckes M, Ramirez R, Torres J, Luna-Herrera J: Activity against multidrug-resistant Mycobacterium tuberculosis in Mexican plants used to treat respiratory diseases. Phytother Res 2003, 17:903-908.

33. Simões M, Bennett RN, Rosa EA: Understanding antimicrobial activities of phytochemicals against multidrug resistant bacteria and biofilms. Nat Prod Rep 2009, 26:746-757.

34. Kuete V: Potential of Cameroonian plants and derived products against microbial infections: a review. Planta Med 2010, 76:1479-1491.

35. Kuete V, Efferth T: Cameroonian medicinal plants: pharmacology and derived natural products. Front Pharmacol 2010, 1:123

36. Gallo MBC, Sarachine MJ: Biological activities of lupeol. Int/ I Biomed Pharma Sci 2009, 3:46-66.

37. Kuete V, Wansi JD, Mbaveng AT, Kana Sop MM, Tcho Tadjong A, Penlap Beng V, Etoa FX, Wandji J, Marion Meyer JJ, Lall N: Antimicrobial activity of the methanolic extract and compounds from Teclea afzelii (Rutaceae). S Afr J Bot 2008, 74:572-576.

38. Kuete V, Komguem J, Penlap Beng V, Meli AL, Tangmouo JG, Etoa FX, Lontsi D: Antimicrobial components of the methanolic extract from the stem bark of Garcinia smeathmannii Oliver (Clusiaceae). S Afr J Bot 2007, 73:347-354.

39. Kim Y-G, Watanabe N, Sano Y, Uraki Y, Sano Y: Extractives of kitakobusi Magnolia kobus DC. var. borealis Sarg. III.: Antibacterial and Antifungal Activity of Extractives. Res Bull Hokkaido Univ For 1998, 55:63-73.

40. Rahman A, Na M, Kang SC: Antilisterial potential of imperatorin and limonin. J Food Biochem 2012, 36:217-223.

41. Sunthitikawinsakul A, Kongkathip N, Kongkathip B, Phonnakhu S, Daly JW, Spande TF, Nimit Y, Rochanaruangrai S: Coumarins and carbazoles from Clausena excavata exhibited antimycobacterial and antifungal activities. Planta Med 2003, 69:155-157.

42. Kuete V, Metuno R, Ngameni B, Tsafack AM, Ngandeu F, Fotso GW, Bezabih M, Etoa FX, Ngadjui BT, Abegaz BM, Beng VP: Antimicrobial activity of the methanolic extracts and compounds from Treculia obovoidea (Moraceae). J Ethnopharmacol 2007, 112:531-536.

43. Olila D, Opuda-Asibo J: Olwa-Odyek: Bioassay-guided studies on the cytotoxic and in vitro trypanocidal activities of a sesquiterpene (Muzigadial) derived from a Ugandan medicinal plant (Warburgia ugandensis). Afr Health Sci 2001, 1:12-15.

doi:10.1186/1472-6882-13-81

Cite this article as: Fouotsa et al: Antibacterial constituents of three Cameroonian medicinal plants: Garcinia nobilis, Oricia suaveolens and Balsamocitrus camerunensis. BMC Complementary and Alternative Medicine 2013 13:81.

\section{Submit your next manuscript to BioMed Central and take full advantage of:}

- Convenient online submission

- Thorough peer review

- No space constraints or color figure charges

- Immediate publication on acceptance

- Inclusion in PubMed, CAS, Scopus and Google Scholar

- Research which is freely available for redistribution 